\title{
Comparison of different teaching methods for tooth extraction
}

\section{Farklı diş çekimi öğretim metodlarının karşılaştırılması}

\author{
Yeliz Kılınç ${ }^{1^{*}}$ (D), Deniz Yaman ${ }^{2}$ (D) , Aslı Ayaz ${ }^{1}$ (D), Sara Samur Ergüven ${ }^{3}$ (D), Nur Mollaoğlu 4 (iD \\ ${ }^{1}$ Registrar, Department of Oral \& Maxillofacial Surgery, Gazi University, School of Dentistry, Ankara, Turkey \\ ${ }^{2}$ Research Assistant, Department of Oral \& Maxillofacial Surgery, Gazi University, School of Dentistry, Ankara, Turkey \\ ${ }^{3}$ DDS, PhD, 75. Yıl Oral and Dental Health Center, Ankara, Turkey \\ ${ }^{4}$ Professor, Department of Oral \& Maxillofacial Surgery, Gazi University, School of Dentistry, Ankara, Turkey \\ * Corresponding author: Yeliz Kılınç E-mail: dtykilinc@gmail.com ORCID: 0000-0003-2853-7830 \\ Received: 14 August 2018 Accepted: 7 January 2019
}

\begin{abstract}
Aim: Undergraduate dental education has been an important issue on oral surgery and there have been many tools to improve the skills of dental students. The aim of this study was to assess two different teaching methods on oral surgery for undergraduate dental education.
\end{abstract}

Material and Methods: A total of 84 third-year dental students without any declared previous experience on surgery were divided into two groups. Group 1 was given a lecture and slide presentation regarding the extraction of teeth 17 and 37. Group 2 received a demonstration of tooth extraction performed on the plastic skull model in addition to lecture and slide presentation. Baseline knowledge was measured using a questionnaire that consisted of 14-item check list. Data analysis was carried out using the SPSS (version 15) statistical software package. One-Sample Kolmogorov-Smirnov test and Kruskal Wallis test were performed for the statistical assessment.

Results: Group 2 presented statistically significant better learning scores. Demonstration was determined to be related with higher scores.

Conclusions: The present study reveals that demonstration is more beneficial in teaching basic surgical skills for tooth extraction. Thus, teaching methods are suggested to be performed with demonstration in the preclinical educational programs.

Keywords: dental education, dental students, oral surgery, teaching 


\section{öz}

Amaç: Diş hekimliği eğitiminde oral cerrahinin yeri önemlidir ve diş hekimliği öğrencilerinin becerilerini geliştirmek için pek çok yöntem mevcuttur. Bu çalışmanın amacı diş hekimliği eğitiminde oral cerrahide iki farklı öğretim yönteminin değerlendirilmesidir.

Gereç ve Yöntemler: Daha önce oral cerrahi deneyimi olmayan toplam 84 üçüncü sınıf öğrencisi iki gruba ayrıldı. Grup 1'e 17 ve 37 nolu dişlerin çekimi ile ilgili bir ders ve slayt sunumu yapıldı. Grup 2'ye ders ve slayt sunumuna ek olarak kafatası modeli üzerinde diş çekimi demonstrasyonu yapıldı. Temel bilgi kazanımı 14 maddelik kontrol listesinden oluşan bir anket kullanılarak ölçüldü. Veri analizi SPSS (Sürüm 15) istatistik yazılım paketi kullanılarak gerçekleştirildi. İstatistiksel değerlendirme için Kolmogorov Smirnov tek örnek testi ve Kruskal Wallis testi kullanıldı.

Bulgular: Grup 2'de istatistiksel olarak daha anlamlı öğrenme skorları gözlendi. Demonstrasyonun daha yüksek öğrenme skorları ile ilişkili olduğu belirlendi.

Sonuçlar: Bu çalışma diş çekimi için temel cerrahi becerilerin öğretilmesinde model üzerinde yapılan demonstrasyonun daha yararlı olduğunu ortaya koymaktadır. Bu nedenle, öğretim yöntemlerinin klinik öncesi eğitim programlarında demonstrasyon ile gerçekleştirilmesi önerilmektedir.

Anahtar kelimeler: diş hekimliği eğitimi, diş hekimliği öğrencileri, oral cerrahi, öğretme

\section{INTRODUCTION}

Over the years undergraduate dental education has displayed an important advancement in order to improve the skill of dental students. There have been many hand tools and equipments used for a proper dental treatment. Using the most appropriate hand tool makes all the dental procedure easier for both the practitioners and patients. Decision making and using appropriate hand tools gets more important in particularly when it comes to dental surgery. Tooth extraction is the most frightening dental intervention for patients and also comes more complicated for undergraduate dental students. In addition, teaching the technique and forceps used for extraction may sometimes be quite challenging for the lecturers as well.

Educational assessments constitute a critical part of successful education for acquisition of skills. Scientific knowledge, precise intervention and professional values have been defined to be the important part of the competent practice of dentistry. Recently there have been reports in the dental education literature such as problembased or case-reinforced learning in order to help developing student's clinical skills and also help students to gain insight for evidence-based oral health care [1-5].

Preclinical dental teaching and learning involves only theoretical knowledge which is gradually developed by practical training in time. Students do improve their knowledge throughout their undergraduate education and the rest of their career step by step during their clinical observations and practice based procedural learning [6]. When it comes to oral surgery, it is relatively more invasive than the rest of the dental disciplines for undergraduate dental students. Therefore, improving teaching techniques for more competitive dental education is carrying out great importance by every other day. Competent surgical preclinical training should include assessment of dental students' knowledge and practical skill [7]. Thus, the aim of our study is to evaluate the two different preclinical teaching models with and without demonstration carried out at our department.

\section{MATERIAL AND METHODS}

This study was carried out at Gazi University, School of Dentistry in Ankara, Turkey. Total of 84 third-year dental students took part in this study. Their involvement was voluntary and only individuals without any declared previous experience on surgery were included. All the participants agreed to be included in the study and signed a written informed consent. Ethical approval was obtained from the university ethics committee prior to the onset of the study (25901600-217). The study was conducted according to the Declaration of Helsinki. Participants were randomly divided into two groups and each group received a different teaching method, given by the same senior registrar (DY).

Group 1 ( $n=33$ ): Students were given a 30 minutes of lecture by a senior registrar. During the lecture extraction of teeth 17 (model 1) and 37 (model 2) were explained theoretically 
Table 1. Percentage of correct answers for extracting tooth 17 in Group 1 and 2

\begin{tabular}{|c|c|c|}
\hline Questions: Q & Group 1 & Group 2 \\
\hline & $\begin{array}{c}\text { Correct } \\
n(\%)\end{array}$ & $\begin{array}{c}\text { Correct } \\
\text { n (\%) }\end{array}$ \\
\hline Q1. Where practitioner should stand during extraction? & $28(84.8)$ & $48(94.1)$ \\
\hline Q2. Choosing the correct forceps & $23(69.7)$ & $44(86.3)$ \\
\hline Q3. How to hold the forceps during extraction? & $17(51.5)$ & $41(80.4)$ \\
\hline Q4. While one hand is holding the forceps how to place the other hand to assist during extraction? & $18(54.5)$ & $38(74.5)$ \\
\hline Q5. Choosing the correct elevator & $33(100)$ & $49(96.1)$ \\
\hline Q6. Choosing the correct elevator when the tooth is broken from cervical line & 30 (90.9) & $47(92.2)$ \\
\hline
\end{tabular}

Table 2. Percentage of correct answers for extracting tooth 37 in Group 1 and 2

\begin{tabular}{|c|c|c|}
\hline Questions: Q & Group 1 & Group 2 \\
\hline & $\begin{array}{c}\text { Correct } \\
\text { n (\%) }\end{array}$ & $\begin{array}{c}\text { Correct } \\
\text { n (\%) }\end{array}$ \\
\hline Q1. Where practitioner should stand while extracting tooth 37 ? & $26(78.8)$ & $41(80.4)$ \\
\hline Q2. Choosing the correct forceps & $20(60.6)$ & $38(74.5)$ \\
\hline Q3. How to hold the forceps during extraction? & $19(57.6)$ & 36 (70.6) \\
\hline Q4. While one hand is holding the forceps how to place the other hand to assist during extraction? & $18(54.5)$ & $31(60.8)$ \\
\hline Q5. Choosing the correct elevator & $22(66.7)$ & $42(82.4)$ \\
\hline Q6. Choosing the correct elevator when the tooth is broken from cervical line & $23(69.7)$ & $41(80.4)$ \\
\hline Q7. Choosing the correct elevator when the tooth is broken from cervical line and only mesial root needed to be taken out & $22(66.7)$ & $41(80.4)$ \\
\hline Q8. Choosing the correct elevator when the tooth is broken from cervical line and only distal root needed to be taken out & $22(66.7)$ & $41(80.4)$ \\
\hline
\end{tabular}

Table 3. One-Sample Kolmogorov Smirnov Test

\begin{tabular}{|c|c|c|c|c|c|c|c|c|}
\hline Tooth37 & Q1 & Q2 & Q3 & Q4 & Q5 & Q6 & Q7 & Q8 \\
\hline Mean & 1.2024 & 1.3095 & 1.3452 & 1.4167 & 1.2381 & 1.2381 & 1.2500 & 1.2500 \\
\hline Std.Deviation & .40419 & .46507 & .47830 & .49597 & .42848 & .42848 & .43561 & .43561 \\
\hline Kolmogorov-Smirnov Z & 4.485 & 4.011 & 3.845 & 3.509 & 4.332 & 4.332 & 4.280 & 4.280 \\
\hline Asymp. Sig. & .000 & .000 & .000 & .000 & .000 & .000 & .000 & .000 \\
\hline Tooth 17 & $\mathbf{Q 1}$ & $\mathbf{Q 2}$ & $\mathbf{Q 3}$ & $\mathbf{Q 4}$ & $\mathbf{Q 5}$ & $\mathbf{Q 6}$ & & \\
\hline Mean & 1.0952 & 1.2024 & 1.3095 & 1.3333 & 1.0238 & 1.0833 & & \\
\hline Std. Deviation & .29531 & .40419 & .46507 & .47424 & .15337 & .27805 & & \\
\hline Kolmogorov-Smirnov Z & 4.869 & 4.485 & 4.011 & 3.901 & 4.930 & 4.898 & & \\
\hline Asymp. Sig. & .000 & .000 & .000 & .000 & .000 & .000 & & \\
\hline
\end{tabular}

${ }^{*} \mathrm{p}<0.05$; Q: Question

to the students. A slide presentation describing the basic surgical concepts was provided during the lecture.

Group $2(n=51)$ : Students in this group received also a slide presentation describing the extraction of teeth 17 and 37 . In addition, following the presentation they also received a demonstration of tooth extraction performed on the plastic skull model by a senior registrar.

Baseline knowledge and knowledge gain was measured using a purposely developed questionnaire that consisted of 14-item skill performance check list regarding tooth extraction including; technique, forceps and patient-dentist position during the extraction (Tables 1 and 2). Each participant was assessed individually by an examiner in the clinic. Correct and incorrect answers were recorded for the statistical analysis.

Data analysis was carried out using the SPSS (version 15) statistical software package in order to check the significant differences between two techniques. The normality of the distribution of the variables was assessed through the onesample Kolmogorov Smirnov test in order to determine which test should be conducted on the data (Table 3). Onesample Kolmogorov Smirnov test revealed that the distribution was not normal $(p<0.05)$. Therefore, Kruskal Wallis test was performed in order to determine if there was a significant difference between Group 1 and Group 2

(Table 4a).

\section{RESULTS}

Group 1 consisted of 33 students; 21 females and 12 male students. Group 2 was composed of 51 students; of which 33 were female and 18 were male students. The average age was 22.35. When the total scores for the correct answers given was compared in between two groups, it was found to be statistically significant ( $p<0.05$ ) (Table 4a), which means students in Group 2 displayed a better performance for both 
Table 4a. Kruskal Wallis Test run between Group 1 and Group 2 in total

\begin{tabular}{|c|c|c|}
\hline Groups & $\mathbf{N}$ & Mean Rank \\
\hline Group 1 & 33 & 33.80 \\
\hline Group 2 & 51 & 48.13 \\
\hline Total & 84 & \\
\hline${ }^{*} \mathrm{p}<0.05$ & Asymp. Sig. .008 \\
\hline
\end{tabular}

Table 4b. Kruskal Wallis Test run for each question between Group 1 and 2

\begin{tabular}{|c|c|c|c|c|c|c|c|c|}
\hline Tooth37 & Q1 & Q2 & Q3 & Q4 & Q5 & Q6 & Q7 & Q8 \\
\hline Chi-Square & .032 & 1.791 & 1.483 & .317 & 2.685 & 1.248 & 1.989 & 1.989 \\
\hline $\mathrm{df}$ & 1 & 1 & 1 & 1 & 1 & 1 & 1 & 1 \\
\hline Asymp. Sig & .859 & .181 & .223 & .573 & .101 & .264 & .158 & .158 \\
\hline Tooth 17 & $\mathbf{Q 1}$ & $\mathbf{Q 2}$ & $\mathbf{Q 3}$ & $\mathbf{Q 4}$ & $\mathbf{Q 5}$ & $\mathbf{Q 6}$ & & \\
\hline Chi-Square & 1.974 & 3.370 & 7.724 & 3.551 & 1.310 & .040 & & \\
\hline $\mathrm{df}$ & 1 & 1 & 1 & 1 & 1 & 1 & & \\
\hline Asymp.Sig & .160 & .066 & $\mathbf{. 0 0 5}$ & .060 & .252 & .841 & & \\
\hline
\end{tabular}

${ }^{*} \mathrm{p}<0.05$; Q: Question

extraction models. The numbers and percentages of the correct answers given for both tooth models were displayed in Tables 1 and 2.

When the percentage of correct answers given in Group 2 was compared one by one separately to answers given in Group 1, it was found to be higher but not statistically significant almost for all the questions. There was only in one question, that the result was statistically significant which is 'How to hold the forceps when removing tooth 17?' (Q3) $(p<0.05)$ (Table 4b).

\section{DISCUSSION}

Assessment should have been the most fundamental component of teaching and learning during basic surgical training. Practical teaching and learning for the basic surgical procedures are taken quite seriously in our institution.

Dental training comprises performing irreversible clinical procedures on patients that students are personally responsible. Therefore, acquisition of clinical skills is stressful for the students. Preclinical training on dental models appears to be a successful approach to facilitate acquisition of complex operative skills by the students, enabling the experience to clinical practice. However, first dental students need to ensure that preclinical education is efficacious to improve confidence prior to the beginning of clinical practice. Thus, variety of educational methods have been used to enhance the clinical skills and knowledge of students in dental schools [8-10].

The present study was performed following the educational program given at Gazi University, School of Dentistry. According to the current preclinical educational program, which consists of theoretical and practical parts, theoretical part includes verbal instructions and slide presentations and the practical part includes training on the bench models and also clinical observations.

Generally, the most common form of teaching basic skills for extraction is model demonstration followed by supervised clinical performance. This aids student recognizing the correct or incorrect applications and understanding the actual points of the surgical procedure [11]. In this study, two different learning methods were evaluated. The traditional approach given to Group 1 involved only lecture along with slide presentation. The active learning group which is Group 2 received a live demonstration on the bench model in addition to the lecture. Tooth extraction, especially when it comes to posterior teeth, requires good clinical skill to make the correct diagnosis and treatment planning. Therefore extraction of tooth 17 and 37 was chosen as a surgical model.

The results indicated that Group 2 had given better answers to questionnaire, consequently having higher scores compared to Group 1. One explanation for this result might be live demonstration on the bench (skull) model may contain more sufficient information for learning basic surgical skills for tooth extraction being in agreement with other studies that bench model demonstration plus traditional learning significantly enhances learning among students $[9,12,13]$. Among all the questions Q3 and Q4 were the least well answered questions in both Groups for both extraction models. It seems that it is important to utilize interactive teaching strategies as reported previously by other studies $[9,14,15]$. However, results also indicate that students in Group 2 have answered Q3 significantly better than Group $1 \quad(p<0.05) \quad($ Table $4 \mathbf{b})$, supporting the 
importance of interactive teaching methods. Q5 was also one of the most well answered questions. This result may indicate that students can learn elevators easier than forceps. Therefore, when teaching forceps using more demonstrative teaching methods may be more efficient.

In addition, most surgical training programs do also benefit from the use of a variety of models including inanimate models, virtual reality, live animals and human cadavers [1619]. The integration of skills training through the use of these models provides a simulation for human living tissue as well as enabling team training. Human cadavers have the closest reality; however the use of cadavers is limited due to their cost, availability and poor compliance of cadaveric tissue. Moreover, ethical issues, high costs and the need for specialized facilities make the use of live animals difficult for surgical training. Nevertheless, inanimate models are accessible, inexpensive, safe and easily portable when compared to animal models or cadavers [20]. Thus in the present study a simple bench model was preferred to be used, although it could be considered a simple teaching method.

Except all these teaching methods, new technologies in student training are also being developed. These technologies include virtual reality and associated technology. Virtual reality and associated technology has the advantage for early surgical training and evaluating the capacity for motor competency skills [21]. Recent advances indicated that virtual reality is a valuable educational tool for enhancing surgical skill training and also provides to the user an instant feedback and allows for a detailed assessment of the trainee performance [20]. The present study does also indicate the need of different teaching methods for better training such as virtual reality as there found to be higher results between two teaching methods given to undergraduates (Table 4a). Aspegren concluded that instructional methods like lectures were unsatisfactory when compared to experiential methods such as interviewing simulated patients and receiving immediate feedback from the instructors. Students may also more likely to desire experimental methods than instructional ones [22].

Moreover, videotaped role-plays were also found to be quite beneficial for the assessment of communication skills. Evans evaluated that lectures and skills workshops as methods of learning communication skills and found that students undergoing to skills workshops demonstrated more significant improvement in interview skills compared to the students taking just lectures [23]. Therefore, it is important to support traditional methods with other interactive methods.

In summary, the present study determined that demonstration is an effective method for teaching students basic surgical skills for tooth extraction. However, it also indicated a need of upgrading teaching methods to enhance the practical skills of students in our institution. Following the current advances such as video training and patient simulation besides bench model demonstration will surely be more beneficial to improve learning capacity of dental students to enhance their surgical skills.

\section{DECLARATION OF CONFLICT OF INTEREST}

The authors received no financial support for the research and/or authorship of this article. There is no conflict of interest.

\section{REFERENCES}

1. Rich SK, Keim RG, Shuler CF. Problem-based learning versus a traditional educational methodology: a comparison of preclinical and clinical periodontics performance. J Dent Educ 2005; 69: 649-62.

2. Zhang SY, Zheng JW, Yang C, et al. Case-based learning in clinical courses in a Chinese college of stomatology. J Dent Educ 2012; 76: 1389-92.

3. Garvey MT, O'Sullivan M, Blake M. Multidisciplinary casebased learning for undergraduate students. Eur J Dent Educ 2000; 4: 165-8.

4. von Bergmann $\mathrm{H}$, Walker J, Dalrymple KR, Shuler CF. Dental Faculty Members' Pedagogic Beliefs and Curriculum Aims in Problem-Based Learning: An Exploratory Study. J Dent Educ 2017; 81: 937-47. (doi: 10.21815/JDE.017.046).

5. Albino JE, Young SK, Neumann LM, et al. Assessing dental students' competence: best practice recommendations in the performance assessment literature and investigation of current practices in predoctoral dental education. J Dent Educ 2008; 72: 1405-35.

6. Chuenjitwongsa S, Oliver RG, Bullock AD. Competence, competency-based education, and undergraduate dental education: a discussion paper. Eur J Dent Educ 2018; 22: 1-8. (doi: 10.1111/eje.12213). Epub 2016 Jun 1. 
7. Macluskey M, Hanson C, Kershaw A, Wight AJ, Ogden GR. Development of a structured clinical operative test (SCOT) in the assessment of practical ability in the oral surgery undergraduate curriculum. Br Dent J 2004; 196: 225-8.

8. Corrêa L, De Campos AC, Souza SC, Novelli MD. Teaching oral surgery to undergraduate students: a pilot study using a Web-based practical course. Eur J Dent Educ 2003; 7: 111-5.

9. Dantas AK, Shinagawa A, Deboni MC. Assessment of preclinical learning on oral surgery using three instructional strategies. J Dent Educ 2010; 74: 1230-6.

10. Ali K, Heffernan E, Lambe P, Coombes L. Use of peer assessment in tooth extraction competency. Eur J Dent Educ 2014; 18: 44-50.

11. Norris TE, Cullison SW, Fihn SD. Teaching procedural skills. J Gen Intern Med 1997; 12: 64-70.

12. Denadai R, Souto LR. Organic bench model to complement the teaching and learning on basic surgical skills. Acta Cir Bras 2012; 27: 88-94.

13. Denadai R, Oshiiwa M, Saad-Hossne R. Does bench model fidelity interfere in the acquisition of suture skills by novice medical students? Rev Assoc Méd Bras (1992) 2012; 58: 600-6.

14. Eitner S, Holst S, Wichmann M, Karl M, Nkenke E, Schlegel A. Comparative study on interactive computer-aidedlearning and computer-aided-testing in patient-based dental training in maxillofacial surgery. Eur J Dent Educ 2008; 12: 35-40.
15. Omar E. Perceptions of Teaching Methods for Preclinical Oral Surgery: A Comparison with Learning Styles. Open Dent J 2017; 11: 109-19. (doi: 10.2174/1874210601711010109). eCollection 2017.

16. Rodriguez O, Sanchez-Ismayel A, Sanchez R, Pena R, Salamo $O$. Construct validity of an inanimate training model for laparoscopic appendectomy. JSLS 2013; 17: 445-9.

17. Miki T, Iwai T, Kotani K, Dang J, Sawada H, Miyake M. Development of a virtual reality training system for endoscope-assisted submandibular gland removal. J Craniomaxillofac Surg 2016; 44: 1800-5.

18. DeMasi SC, Katsuta E, Takabe K. Live animals for preclinical medical student surgical training. Edorium J Surg 2016; 3: 24-31.

19. Krähenbühl SM, Čvančara $P$, Stieglitz $T$, et al. Return of the cadaver: Key role of anatomic dissection for plastic surgery resident training. Medicine (Baltimore) 2017; 96: e7528. (doi: 10.1097/MD.0000000000007528).

20. Reznick RK, MacRae H. Teaching surgical skills—changes in the wind. N Engl J Med 2006; 355: 2664-9.

21. Evans AW. Assessing competence in surgical dentistry. $\mathrm{Br}$ Dent J 2001; 190: 343-6.

22. Aspegren K. BEME Guide No. 2: Teaching and learning communication skills in medicine-a review with quality grading of articles. Medical Teach 1999; 21: 563-70.

23. Evans BJ, Stanley RO, Burrows GD, Sweet B. Lectures and skills workshops as teaching formats in a history-taking skills course for medical students. Med Educ 1989; 23; 364-70. 